\title{
Tectonic elements of the continental margin of East Antarctica, $38-164^{\circ} \mathrm{E}$
}

\author{
P. E. O'Brien and H. M. J. Stagg \\ Geoscience Australia, GPO Box 378, Canberra ACT 2601, Australia (phil.obrien@ga.gov.au, howard.stagg@ga.gov.au)
}

\begin{abstract}
The East Antarctic continental margin from $38-164^{\circ} \mathrm{E}$ is divided into western and eastern provinces that developed during the separation of India from Australia-Antarctica (Early Cretaceous) and Australia from Antarctica (Late Cretaceous). In the overlap between these provinces the geology is complex and bears the imprint of both extension/spreading episodes, with an overprinting of volcanism. The main rift-bounding faults appear to approximately coincide with the outer edge of the continental shelf. Inboard of these faults, the sedimentary cover thins above shallowing basement towards the coast where crystalline basement generally crops out. The continental slope and the landward flanks of the ocean basins, are blanketed by up to 9-10 km of mainly post-rift sediments in marginparallel basins, except in the Bruce Rise area. Beneath this blanket, extensive rift basins are identified off Enderby and Wilkes Land/Terre Adélie; however, their extent and detailed structures are difficult to determine.
\end{abstract}

Citation: O’Brien, P.E., and H.M.J. Stagg (2007), Tectonic elements of the continental margin of East Antarctica, 38-164 E: in Antarctica: A Keystone in a Changing World - Online Proceedings of the $10^{\text {th }}$ International Symposium on Antarctic Earth Sciences, edited by A.K. Cooper and C.R. Raymond et al., USGS Open-File Report 2007-1047, Short Research Paper 085, 4 p.; doi:10.3133/of2007-1047.srp085

\section{Introduction}

Since the early 1980s, the continental margin of East Antarctica has been investigated by seismic surveys carried out by the Antarctic programs of Australia, Russia, Japan, France, Norway, USA and Italy. The acquisition of high-quality deep-seismic data from 38$164^{\circ} \mathrm{E}$ in 2001 and 2002 (Stagg et al., 2005) allow the compilation of maps of the main tectonic elements of the continental margin using a seismic data set of consistent quality (Figs. 1, 2). Tectonic element maps have been published for the Enderby Land-Kerguelen Sector (Stagg et al. 2004), Bruce Rise (Stagg et al., (in press) and Wilkes land (Colwell et al., 2005). Stagg et al. (2005) produced a map of the whole region.

The regional tectonic elements are shown here in two overlapping maps of the margin (Fig. 3) and we summarise the geology of the major elements that can be interpreted. This interpretation is restricted in its landward extent, mainly because of the very limited seismic coverage of the continental shelf other than in Prydz Bay. However, the maps provide a basic framework on which further studies will be able to build as new data become available through the Scientific Committee for Antarctic research (SCAR) Seismic Data Library System (SDLS).

\section{General form of the margin}

The mainly amagmatic East Antarctic continental margin from $38-164^{\circ} \mathrm{E}$ formed through the rifting and breakup of Greater India from Antarctica in the west, culminating in the Hauterivian (Brown et al., 2003), and of Australia from Antarctica, culminating in the Late Cretaceous (e.g. Sayers et al., 2001). The continental margin is a normal rifted margin, bounded by a dextral oblique-slip sector in the far west and a sinistral obliqueslip sector in the far east. The central part of the margin has added structural complexities due to the spatial and temporal overlap of the two breakup episodes.

The inboard, shelfal flank of the rift is rarely imaged

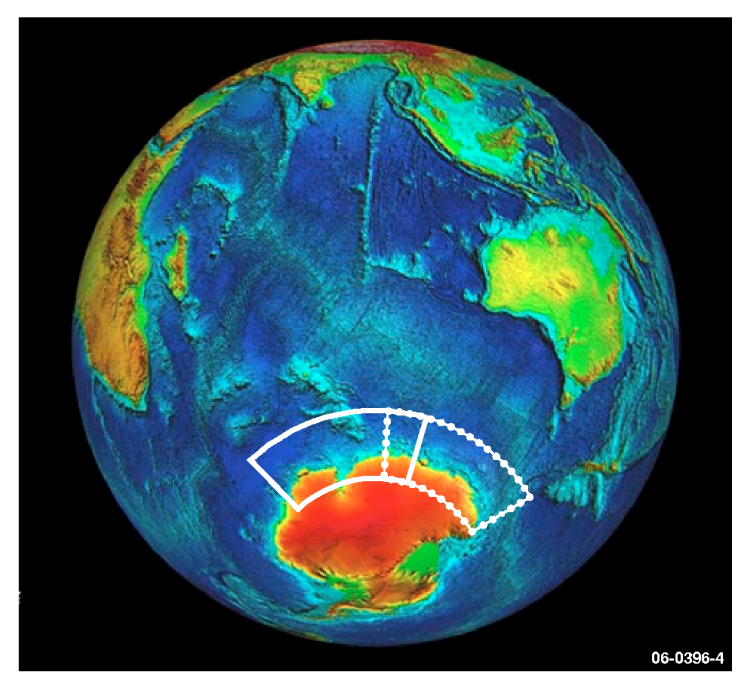

Figure 1. Topographic image of the Indian and Southern Ocean region (image from National Oceanographic and Atmospheric Administration), showing the locations of the maps in Figures 3.

in seismic data, due to persistent sea ice cover, which makes surveying difficult, and to the ubiquitously strong seismic multiples, which make it difficult to distinguish rift structures. However, in general it appears that the main rift-bounding faults approximately coincide with the outer edge of the continental shelf. Sedimentary cover of varying thickness extends inboard of the rift-bounding faults and this cover thins above shallowing basement towards the coast. Seismic data indicate that the innermost shelf is underlain by outcropping crystalline basement, except beneath southwest Prydz Bay.

The continental slope and the landward flanks of the deep ocean basins are generally blanketed by a large thickness of sediments. The post-rift sedimentary section is particularly thick, as much as $9-10 \mathrm{~km}$ thick off western Wilkes Land (Close et al., 2007). This limits seismic penetration of the rift and pre-rift section, and 
makes the thickness and structural disposition of this part of the section difficult to discern. Therefore, the location of depocentres on the maps in Figure 3 is mainly a guide to the post-rift depocentres. The seaward extent of the continental margin basins is often indeterminate, as the sediments gradually thin northwards onto oceanic crust over a distance of hundreds of kilometres from the continental margin.

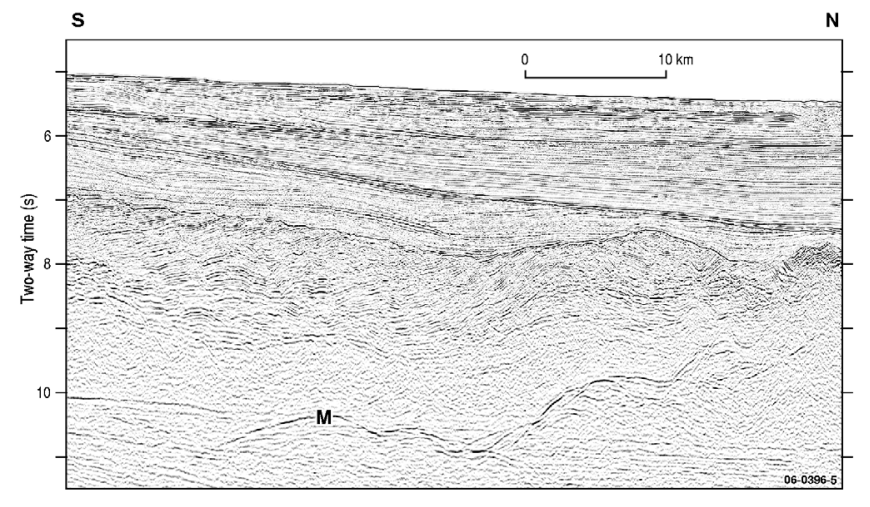

Figure 2. Part of deep-seismic profile GA-228/24 from offshore Wilkes Land, showing the quality of the data underpinning the maps in Figure 3 The crust is clearly divided into post-rift ( $\sim 5-7.5 \mathrm{~s}$ two-way time) and rift (( 7.5-9 s) sections, overlying seismically transparent ?crystalline crust ( $\sim-10 \mathrm{~s})$ and reflection Moho ('M').

Identification of the continent-ocean boundary (COB), the inboard edge of oceanic crust identified in seismic data, supported by gravity and magnetic interpretation, varies from clearly defined to imprecise and/or controversial. Off Enderby Land, Bruce Rise, central and eastern Wilkes Land and Terre Adélie George V Land, the boundary between oceanic crust and the outboard edge of highly extended and/or modified continental crust (which may include fragments of protooceanic crust) is generally clearly defined on the basis of seismic character. In places, this definition is supported by dredge samples and by seismic correlations with the conjugate southern Australian margin. Between the Princess Elizabeth Trough and the western flank of Bruce Rise, the available seismic profiles frequently do not extend far enough landward to define the $\mathrm{COB}$, although it appears to be located well inboard on this part of the margin. The most tentative identification of the $\mathrm{COB}$ is off western Wilkes Land $\left(102-123^{\circ} \mathrm{E}\right)$, where the extremely thick and highly reflective post-rift sedimentary section degrades seismic penetration of the underlying section. The location of the COB shown for this sector in Figure 3 is its most outboard position; on Russian data in the same area (G. Leitchenkov, pers. comm.), the $\mathrm{COB}$ has been interpreted to lie a considerable distance further inboard.

\section{Major tectonic elements \\ Rayner Basin}

The Rayner Basin is a narrow, NE-SW trending, midto upper-slope basin located between the shelf edge and the western Enderby Basin, in an oblique-slip tectonic setting (Stagg et al., 2004). There is little indication of a rift section, and the basin contains a maximum of $4 \mathrm{~s}$ twoway time (twt; $c a .6 \mathrm{~km}$ ) of mainly post-rift sediments. The strike extent of the basin cannot be defined with the existing data.

\section{Mawson and Prydz Bay Basins}

The Mawson Basin is a broad, E-W trending basin located outboard of the shelf break above normal-rifted, deeply subsided continental crust and the inboard flank of the oceanic crust of the Enderby Basin (Stagg et al., 2004). Some pre-rift section is visible in underlying fault blocks, but the major thickness of sediments $(>8 \mathrm{~km})$ is of post-rift origin, with the main depocentre being located beneath the upper continental slope. The ?Jurassic to Early Cretaceous Prydz Bay Basin is a N-S trending basin that is underlain by the Lambert Graben (Stagg, 1985). The shallow section in this basin has been extensively investigated by seismic recording and drilling by the Ocean Drilling Program; however, the total thickness of sediments is unknown, although estimated to be greater than $5 \mathrm{~km}$. The orthogonal trends of the Mawson and Prydz Bay Basins make it likely that the rift structures oceanwards of Prydz Bay are highly complex.

\section{Princess Elizabeth Trough}

The Princess Elizabeth Trough separates the Cretaceous, predominantly volcanic southern Kerguelen Plateau, from the Antarctic margin. The single Japanese seismic profile available through the SDLS shows a maximum sediment thickness of about $3 \mathrm{~s}$ twt $(>4 \mathrm{~km})$ beneath the southern flank of the trough. The continentocean boundary is interpreted to be located close to the Antarctic margin and the trough is mainly underlain by oceanic crust.

\section{Shackleton Basin}

The Shackleton Basin is a complex morphological and geological basin that encompasses the deep-water area from the eastern end of the Princess Elizabeth Trough and the southern Kerguelen Plateau to east of the Bruce Rise, and from the continental slope to the fast-spreading Eocene oceanic crust of the Australian-Antarctic Basin (Stagg et al., in press). While the crust is interpreted to be largely oceanic (magnetic spreading anomalies M4y and M9y were identified in Stagg et al., 2005), it is also highly heterogeneous in seismic character and shows evidence of widespread extensional faulting. This faulting may indicate re-rifting of old oceanic crust; alternatively, the basin may also contain some small continental fragments that were formerly attached to the 

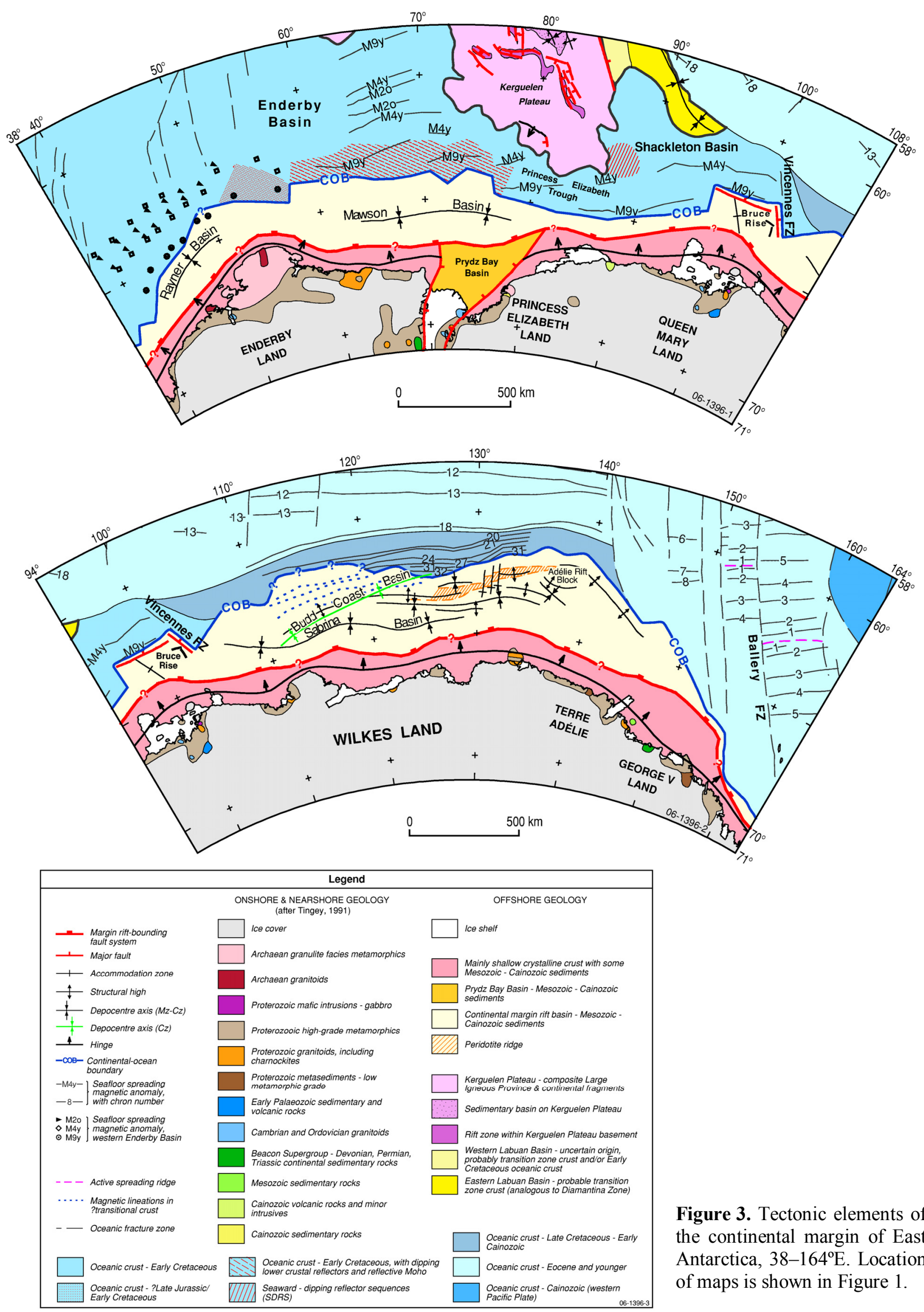

Figure 3. Tectonic elements of the continental margin of East Antarctica, $38-164^{\circ}$ E. Location of maps is shown in Figure 1. 
Antarctic margin. Prominent seaward-dipping reflector sequences are identified in the west of the basin adjacent to the Kerguelen Plateau. The Shackleton Basin contains 2-4 km of mainly flat-lying, post-rift sediments.

\section{Bruce Rise}

The Bruce Rise (also referred to as Bruce Bank by Russian investigators) is a rare marginal plateau on the Antarctic continental margin. Bruce Rise comprises an eastern part that appears to consist of crystalline continental basement with minor faulted half-graben, and which is structurally similar to the Naturaliste Plateau off southwest Australia, and a more deeply subsided western part that is probably largely of volcanic origin (Stagg et al., in press). The northern margin of Bruce Rise is controlled by steeply-dipping normal faults, while the eastern margin is controlled by the NW-SE trending, very steeply dipping Vincennes Fracture Zone, which is a probable conjugate of the Naturaliste Fracture Zone at the southwest corner of the Naturaliste Plateau.

\section{Wilkes Land margin}

The ca. $1500 \mathrm{~km}$-long continental margin off Wilkes Land is underlain by extensive margin-parallel rift and post-rift basins, formed during the separation of Antarctica and Australia (Colwell et al., 2006). The continental slope is underlain by a clearly-defined ?Jurassic-Cretaceous rift and post-rift basin (Sabrina Basin) containing a total thickness of more than $4 \mathrm{~s}$ twt $(>6 \mathrm{~km})$ of sedimentary rocks in a depocentre between the rift-bounding fault system beneath the shelf edge and a basement ridge beneath the inboard flank of the Australian-Antarctic Basin. The basement ridge is interpreted to be mainly unroofed mantle peridotites, similar to the peridotite ridge on the Iberian margin, and has a conjugate structure on the Australian margin (Colwell et al., 2006). While the post-rift sedimentary section is ubiquitously thick, it is particularly concentrated in a major depocentre that trends oblique to the margin (the Budd Coast Basin). This depocentre contains at least $9 \mathrm{~km}$ of post-rift sediments, and which were interpreted by Close et al. (2007) to be largely glacially derived in the post-Eocene.

\section{Adélie Rift Block}

Between the eastern end of the Wilkes Land margin sector and the oblique-slip margin that formed by the separation of Tasmania / southeast Australia and George V Land - Oates Land, the margin is underlain by a deeply-subsided block of rifted crust (Adélie Rift Block; Colwell et al., 2006), whose continental origins are attested by dredging (Tanahashi et al., 1997; Yuasa et al., 1997) and its seismic character, which strongly resembles the rift section of the Otway Basin of southeast Australia. The Adélie Rift Block was almost separated from the Antarctic margin during Late Cretaceous margin breakup.

\section{Conclusions}

The seismic data acquired by Australia in 2001/02 provide a good basis for defining the broad-scale geological structures and the sediment distribution on more than one-third of the Antarctic continental margin. As new data become available through the SCAR SDLS, this understanding will be enhanced through integrated stratigraphic and structural interpretations. The two major shortcomings in our current knowledge of the margin are on the continental shelf, where ice conditions make operations uncertain at the best of times, and in the rift and pre-rift section where the seismic penetration is restricted by the often immensely thick overburden. Addressing these shortcomings - particularly through the acquisition of deep-seismic reflection and velocity data is an important focus for long-term marine geoscience in offshore Antarctica.

Acknowledgements. The authors thank Alix Post and Tony Stephenson for their constructive reviews of the paper. The figures were drafted by Angie Jaensch and Silvio Mezzomo. This paper is published with the permission of the Chief Executive Officer, Geoscience Australia.

\section{References}

Brown, B. J., T. Ishihara, and R. D. Müller (2003), Breakup and seafloor spreading between Antarctica, greater India and Australia, in Abstracts $9^{\text {th }}$ International Symposium on Antarctic Earth Sciences, edited by D. K. Fütterer, p. 40, Potsdam 8-12 September 2003.

Close, D.I., H. M. J. Stagg, and P. E. O’Brien (2007), Seismic stratigraphy and sediment distribution on the Wilkes Land and Terre Adélie margins, East Antarctica, Marine Geology, 239, 33-57.

Colwell, J. B., H. M. J. Stagg, N. G. Direen, G. Bernardel, and I. Borissova (2006), The structure of the continental margin off Wilkes Land and Terre Adélie, East Antarctica, in Antarctica: Contributions to Global Earth Sciences, edited by D. K. Fütterer, D. Damaske, G. Kleinschmidt, H. Miller, and F. Tessensohn, pp327-340, SpringerVerlag.

Sayers, J., P. A. Symonds, N. G. Direen, N.G., and G. Bernardel (2001), Nature of the continent-ocean transition on the non-volcanic rifted margin of the central Great Australian Bight, in Non-volcanic rifting of continental margins: a comparison of evidence from land and sea, edited by R. C. L. Wilson, R. B. Whitmarsh and N. Froitzheim, pp 51-76, Geological Society of London, Special Publication, 187.

Stagg, H.M.J., (1985), The structure and origin of Prydz Bay and the Mac.Robertson Shelf, East Antarctica, in Geophysics of the Polar Regions, edited by E. S. Husebye, G. L. Johnson and Y. Kristoffersen, pp 315-340, Tectonophysics, 114.

Stagg, H.M.J., J. B. Colwell, I. Borissova, T. Ishihara, and G. Bernardel (in press), The Bruce Rise area, East Antarctica: formation of a continental margin near the Greater India - Australia - Antarctica triple junction, Terra Antarctica.

Stagg, H.M.J., J. B. Colwell, N. G. Direen, P. E. O’Brien, G. Bernardel, I. Borissova, B. J. Brown, and T. Ishihara (2004), Geology of the continental margin of Enderby and Mac. Robertson Lands, East Antarctica: insights from a new dataset, in East-west Antarctic tectonics and Gondwana break-up $60 \mathrm{~W}$ to $60 \mathrm{E}$, edited by W. Jokat, pp 183-219, Marine Geophysical Researches, 25, 3-4.

Stagg, H.M.J., J. B. Colwell, N. G. Direen, P. E. O’Brien, B. J. Brown, G. Bernardel, I. Borissova, L. Carson, L., and D. B. Close (2005), Geological framework of the continental margin in the region of the Australian Antarctic Territory, Geoscience Australia Record 2004/25.

Tanahashi, M., T. Ishihara, M. Yuasa, F. Murakami, and A. Nishimura (1997), Preliminary report of the TH95 geological and geophysical survey results in the Ross Sea and the Dumont d'Urville Sea, Proceedings of the NIPR Symposium on Antarctic Geosciences, 10, 36-58.

Yuasa, M., K. Niida, T. Ishihara, K. Kisimoto, F. and Murakami (1997), Peridotite dredged from a seamount off Wilkes Land, the Antarctic: emplacement of fertile mantle fragment at early rifting stage between Australia and Antarctica during the final breakup of Gondwanaland, in The Antarctic region: geological evolution and processes, edited by C. A. Ricci, pp 725-730, Terra Antarctica, Siena. 